\title{
Spellonyms as linguo-cultural onomastic units in indigenous folklore
}

\author{
Viktoriya Oschepkova ${ }^{1}$ and Nataliya Solovyeva ${ }^{1,{ }^{*}}$ \\ ${ }^{1}$ Moscow Region State University, 141014, Very Voloshinoy str, 24, city of Mytishi, Moscow \\ Region, Russia
}

\begin{abstract}
The undertaken research replenishes the pool of knowledge about folklore texts and the functions of spellonyms as signs saturated with national and cultural meanings. The study establishes and compares linguistic and cultural characteristics of spellonyms in the onomasticon of Australian and Nanaian aetiological tales. The authors proposed a typology of spellonyms which includes 5 thematic groups: nominations of deities of different nature; nominations of celestial bodies transformed from representatives of the tribe; nominations of objects of worship and magical rituals; nominations of magical natural phenomena; nominations of magical creatures. The results of the research demonstrate a significant prevalence in the number of deity nominations among Australian spellonyms, while the majority of Nanaian spellonyms refer to magical artefacts. The research has also proved the utmost significance of the water element in the folk worldview of Australian Aborigines and the equivalent importance of the water, land and air elements in the Nanai folk worldview. The obvious preference in both folklore traditions is given to nominations of native origin transcribed into the language of translation. The structural types of spellonyms vary from group to group, with the majority of monolexemic nominations.
\end{abstract}

\section{Introduction}

Folklore works are closely related to national and regional traditions of a society, embody values and worldview of their creators, and act as a driving force for creativity and innovation. The undertaken study deals with a rich and diverse folklore heritage of ethnic groups whose social and historical background appears to be similar in many ways. Originally, both Australian aborigines and Nanaians had a primitive communal system, their economy being based on fishing and hunting. The annexation of the territory where they used to live and the enforced contacts with the more developed neighbouring ethnic groups played an important role in their fate, which naturally found its reflection in the folklore.

Some folklore motives found in the Nanaian folklore can be traced in three regions of the world: in the east of South America, in the north-west of North America, and within the IndoPacific part of Asia and Australia. Scientists are wary of admitting the existence of a historical connection between the Asian-Oceanic and American folklore traditions, bearing in mind the

${ }^{*}$ Corresponding author: natavs@list.ru 
huge distance separating Indonesia from Alaska. However, the Amur-Ussuri parallels might establish a link between Alaskan texts and texts recorded in Borneo, Sumatra and the Malay Peninsula [1].

For the indigenous peoples of Australia and Far-Eastern Russia, totemic myths, legends about the origin of certain customs, etiological tales and legends are still sacred. Their role is to pass on to subsequent generations rules, social norms and vision of the creation of the world and establishment of its laws that govern daily life of a person. Moreover, folklore is a dynamic system of knowledge that develops and transforms together with people and their environment, which is of even greater interest to the researcher.

\subsection{Australian Aboriginal folklore narratives}

The body of folklore narratives found in Australia is heterogeneous. Australian Aboriginal narratives are associated with Dreamtime or Dreaming -a complex system of knowledge, beliefs and practices arising from the stories of creation and defining spiritual and physical aspects of Aboriginal life. As noted by E.M. Meletinsky, time in this case is considered as an a historical phenomenon, an era of abundance, recreated in dreams and rituals, the performers of which are identified with mythical totemic ancestors [2]. A feature of the events unfolding during the "time of dreams" is the absence of hyperbolization: the focus is not on the universe, but on a specific territory where totemic ancestors lived.

Maori mythological and religious beliefs have similarities with the beliefs of other Polynesian peoples and embody ideas about the origin of the universe and, therefore, gods, people, living things and natural phenomena. These older beliefs are complemented by the settlement traditions established by the Maori in New Zealand. The oral tradition defined and established social hierarchy, territorial ownership, and tribal relationships.

In addition to the folklore that exists among the indigenous population and has a pronounced sacred character, there exists the folklore of European settlers. Being largely due to the emerging social stratification between prisoners and free emigrants, it reflects the history of European settlements expansion in Australia and New Zealand. The heroes of European settlers' folklore are robbers, gold miners and cattle drivers.

With regard to the genres of European settlers' folklore, B. Scott singles out folk songs, ballads, fables, superstitions and urban legends, but points out the absence of a fairy tale genre in its traditional sense [3]. D. Haase expresses a similar idea concerning the folklore of the indigenous population: "... the term "folk tale" is inappropriate in relation to mythical or legendary stories that exist in the indigenous culture, they cannot be considered simply as entertainment" [4].

A different opinion is expressed by E.M. Meletinsky, who refers to the works of the German ethnographer K. Strelov and claims that the natives themselves distinguish between myths and fairy tales [2]. Collecting fairy tales became possible primarily because some of the narratives lost their sacred meaning and began to play the role of an entertaining or frightening story for the uninitiated.

A key figure in Australian folklore studies is K. Langloh Parker, the author of the classic collections "Folk-lore of the Noongahburrahs as Told to the Piccaninnies" [5] and "More Australian Legendary Tales" [6]. The texts included in the collections are defined by the author as legendary tales. Compared to myths, a legendary tale "is easily enriched with new everyday details, unexpected plot twists, vivid features of the characters, and in this form satisfies both curiosity and the desire for entertainment" [2].

Other significant studies of Australian and New Zealand Aboriginal folklore include W. Ramsey Smith's collection of myths and legends of the Australian aborigines "Myths and Legends of the Australian aboriginals" [7]; the fundamental research by G. Seal "The Hidden Culture: Folklore in Australian Society" [8]; the encyclopedia of Australian folklore "The 
Oxford Companion to Australian Folklore" [9], summarizing the results of research published in the journal "Australian Folklore" and presented at the conferences of the Australian Folk Trust; the work of R. M. Berndt and K. H. Berndt, dedicated to the myths of Australian Aborigines [10]; M. Orbell's encyclopedia of Maori myths and legends [11]; stories of the bush, collected by B. Scott [3].

\subsection{Nanaian folklore narratives}

Folk poetry of the Nanai can be regarded not only as a wonderful phenomenon of literary art, but also as a way to discover the traditional worldview of the nationality, its history and the way of life. Basic genres of the Nanaian narrative folklore are the ningman - tales proper, siokhor - borrowed tales and telungu - myths, legends and mythological tales. Folklore performance was of special importance during hunting or fishing periods. Tales were used to placate masters of the elements, the taiga and water bodies, as well as totemic animals and birds. Telungus were performed in the daytime with a view to bring luck to hunters and fishermen, while ningmans were told in the evening before sleep to chase away the evil spirits.

The term telungu denotes the story of an event that took place in the past. Hence its purely narrative style is devoid of poetic elevation. There are other means which make the story sound more authentic: retelling it from the first person, referring to the source of information or presenting the story as a prophetic dream. Plots are often based on the idea of primordial kinship of men and animals.

Ningmans, which can be considered fairy tales proper, are represented by a variety of types. In the folklore of the Nanai, for whom hunting used to be a life-supporting branch of the household economy, the tale about animals occupies a prominent place. Traditional characters of animal tales are foxes, hares, rats, elks, frogs, bears, sturgeons, pikes, catfish, geese, ducks. Adventures of an animal may form a cycle of a few episodes. However, the initial episode will invariably be a meeting of an animal with a hunter.

Another recognizable layer of ningmans is constituted by stories about heroic characters, specifically bogatyr-girls. Epic heroines of Nanaian folklore live without men and are engaged in hunting. Endowed with supernatural power, they can foresee the future and assume different appearances. An unconventional appearance of a heroine always testifies to her supernatural origin and shamanistic abilities. As N.B. Kile and L.E. Fetisova state, female characters are more archaic than male ones [12]. A mergen - a hero - usually needs helpers to achieve his aim. Most often women personages act as a mergen's helpers.

The fairy tale of everyday life does not stand out in the Nanai folklore, but a few works can be referred to this category. Some of them reveal a deep connection with myths: "the myths about cultural heroes played a significant role in the formation of fairy tales about everyday life and animals" [2].

Borrowed tales named siokhor exist as a special genre variety. As a rule, these are works from the Manchurian and Chinese folklore which were integrated in the Nanai foklore. Plots and characters of siokhor are often very different from those of telungus and ningmans. Siokhors narrate about the lives and adventures of officials, soldiers, townspeople. Interestingly, borrowings from the Russian folklore, also represented by magical and everyday plots (mainly about Ivan the Fool and Emelya), are called locha ningman (literally: Russian fairy tale).

The first attempts at collecting the Nanai folklore were undertaken in the mid-19 ${ }^{\text {th }}$ century by the Russian ethnologist L.I. Schrenck. However, those scattered recordings did not represent the genre system of the Nanai folklore to the full. The first classification of the genres was suggested by the missionary P. Protodyakov, who intuitively singled out dyarin - songs, telungu - myths and ningman - fairy tales [12]. Further on, this classification was 
elaborated by I.A. Lopatin in his work "Fairy tales of the Golds" [13]. The etnonym "Golds" came to be known due to the book by V.K. Arseniev "DersuUsala" while the self-name of Nanaians is "Nani", which means "people of this land". In the middle of the $20^{\text {th }}$ century a comprehensive study of the genres of the Nanai folklore was published by M.A. Kaplan [14]. The latest studies dedicated to the Nanai folklore are "The Nanai. Material culture (second half of the 19th century - mid-20th century). Ethnographic essays" [14] and "The Nanai folklore: Ningman, Siokhor, Telungu" [12].

\subsection{Aetiological tales}

Our research focuses on the magical onomasticon of legendary or aetiological tales. Following O.V. Belova and G.I. Kabakova, we use the term "aetiological tale / legend" in relation to narratives about the origin of the world, man, natural objects and cultural realities, as well as the emergence of customs, prescriptions and social institutions that determine the way of life of the society [16]. Various folklore genres (myths, legends, fairy tales) are integrated in aetiological texts, performing functions of teaching and entertainment. The criteria for differentiating genres are rather vague: what has served as an object of faith may, over time, acquire an entertaining character; the morality contained in the folklore text may lose its relevance.

A similar point of view is expressed by M. Morford and R.J. Lenardon, who assert that myths and fairy tales do not exist in their "pure" form, their elements interpenetrate, fragments of myths masterfully intermingle with fairy tales [17].

A distinctive feature of aetiological texts is their close relationship with the ethnographic context. Many plots, which evolve around creation of the world and man, explain motives of religious and everyday ritual actions characteristic of a particular nationality.

\section{Methods}

Spellonyms have been chosen as the object of this research because they accumulate not only linguistic, but also historical, geographical, ethnographic and sociological information. The study of spellonyms, by which we mean "the names of the characters of a fairy tale that are directly involved in its plot, creating an outlay of the text, moving and transforming within the fairy world" [18], provides a key to understanding not only the beliefs of an ethnic group, but also allows us to assess linguistic creativity, manifested in the nominations of the characters of folk poetry, to trace the evolution of the myth towards the fairy tale.

The purpose of this study is to establish the distinctive features of Australian Aboriginal and Nanaian spellonyms and identify similar and discrepant patterns in the development of folktale onomasticon.

The study material is represented by the corpus of texts in English (58 folktales included in the collections "Australian Legendary Tales" [5] and "More Australian Legendary Tales" [6]) and the corpus of texts in Russian (65 folktales included in the folktale collection "The Nanai folklore: Ningman, Siokhor, Telungu" [12]).

Using the continuous sampling method, we extracted spellonyms from the folktale texts. Descriptive, word-formation and etymological analyses of spellonyms as well as elements of the statistical method were used as research methods.

\section{Results}

The first stage of the research was devoted to the study of specific features of Australian Aboriginal and Nanaian aetiological tales. The analysis made it possible to identify similar 
characteristics:

1) immersion in the real world, manifested in the images of fantastic places which are identical with real-life places;

2) a variety of phenomena that are explained: the appearance of celestial bodies and landscape elements, the habits and appearance of living beings, the origins of ritual actions;

3) the important role of totemic animals and hunting;

4) obligatory references to the objects and rites sacred for the local culture.

At the next stage of the research, a corpus of spellonyms was compiled, including 103 Australian nominations and 86Nanaian nominations. The analysis of the samples enabled us to divide the nominations into several thematic groups: nominations of deities of various nature; nominations of celestial bodies transformed from the representatives of the tribe; nominations of objects of worship and magical rituals; nominations of magical natural phenomena; nominations of magical creatures (Fig. 1).

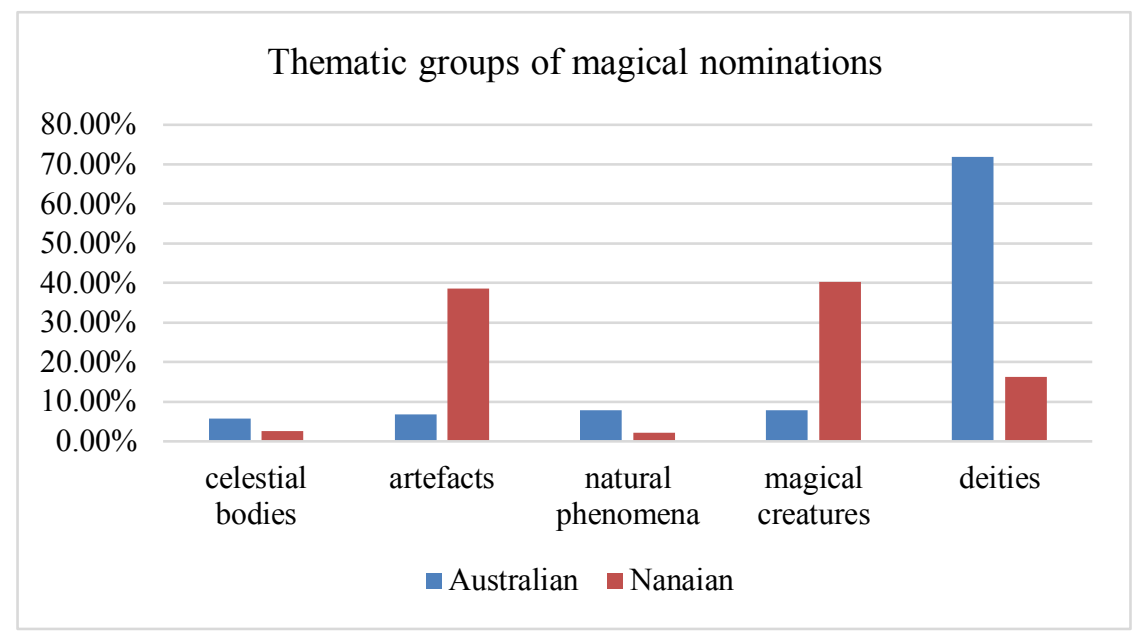

Fig. 1. Thematic groups of magical nominations.

\subsection{Names of deities}

The indigenous religion of Australian is characterized by the presence of gods, whose images are often depicted in some tangible, recognizable form. People are surrounded by the evidence of deities' existence: the real-life landscape resembles the landscape in the "Dreamtime", daily activities largely reconstruct ancestors' activities.

The nominations of the creator deities include: Byamee, Eingana, Birrahgnooloo. Byamee is a creator god that descended to the earth from the sky and created rivers, mountains, forests. In fairy tales, there are two variants of the name-Baiame and Byameeand the adjective old can be used together with the name, emphasizing the god's wisdom. In the tale "The Borah of Byamee" which describes the meeting of tribes and the rite of initiation (borah), the creator god is called the great wizard - Wirreenun: "Old Byamee, who was a great Wirreenun, said he would take his two sons, Gahindahmoee and Boomahoomahnowee, to the gathering of the tribes..." [5]. The text contains two circumlocutory nominations: the mightiest of Wirreenun and doctor of the tribe.

The god's way of life resembles that of people. He is a tribal elder and a family man who brings his people to the tribal meeting: “...Byamee and his tribe, Byahmul the black swans tribe, Oooboon the blue tongued lizards tribe, and many other chiefs and their tribes, each had their camp on a different point" [5]. The first consort of the creator god Eingana is responsible for the creation of people and creatures that live in the water. The second consort 
Birrahgnooloo is the goddess of fertility and floods. Both goddesses are associated with the water element and creatures living in water bodies, which confirms the importance of the water element in the folklore worldview of Australian indigenous people.

Totem deities, combining anthropomorphic and zoomorphic qualities, patronize members of the tribe. In fairy tales, the names of totem deities are most numerous: Dinewan the emu; Oolh the lizard: Quarrian the parrot; Wayarnbeh the turtle; Wurrunnunnah the bees; Googarh the iguana; Moodai the opossum; Byahmul the pelican, etc.

The anthropomorphic nature of totem deities is manifested in their obligatory personification. In the texts of fairy tales, their names correspond to the pronouns he, she, they and the nouns daens / blacks / black fellows, denoting representatives of indigenous population: "GOONUR was a clever old woman-doctor, who lived with her son, Goonur, and his two wives. The wives were Guddah the red lizard, and Beereeun the small, prickly lizard" [5].

Another interesting feature is that bird nominations (emu, magpie, crane, parrot, hawk, eagle, mocking-bird, pigeon, pelican, wagtail, curlew, mopoke, crow, turkey, swan, herron, sea-gull, redbreast) outnumber the nominations of mammals and amphibians (lizard, snake, porcupine, ant-eater, water rat, kangaroo, iguana, opossum, flying squirrel, dog, platypus, turtle, frog), as well as insects and arachnids (bee, fly, butterfly, spider). Presumably, birds as creatures that live on the earth and ascend to the heaven are more likely to be associated with divinity.

Following the Nanaian mind set tales were performed not only for people but also for gods, such as the god of the fire Podia that lived under the earth and the protector of the house Diuli whose wooden figure was kept in a place of honour. The name for the supreme deity is endur / enduri. On the analogy with the Australian folk tradition, anthropomorphic features are inherent in the Nanaian deities, which finds expression in the use of the correlating nouns man, woman and personal pronouns he, she: "Podia is a woman. She lives underground. One man was waiting for her appearance at night in order to marry her" [12].

Unlike the Australian folk tradition with the prevailing water element, the importance of water and land elements in Nanaian folktales is comparable. Each element is represented by a strict social hierarchy, with a god ruling over the creatures inhabiting the element. The nominations include Mue Edeni - the god ruling over rivers; Yohan-god - the god of land and fertility; Hud Gumun - the ruler of the mountains; Kalgama - the ruler of mountains covered in pine forests: "...then another dream came to him: as if he had come to Mue Edeni...Then he began to remember other gods and remembered Yohan-god" [12]. Another powerful deity is Arha Aodinu (literally: Mighty Ruff). It figuratively implies that the deity is endowed with supernatural powers and connected with an important element in the life of Nanaians.

Totem deities, combining anthropomorphic and zoomorphic qualities, patronize not only Australian Aborigines but also Nanaians. Some hunting telungus go back to the ancient totemistic ideas and tell people about Nanaian tribes originating from tiger, bear or some other animal. Nominations of totem deities include: Nangi-bear - an evil deity that lives in the mountains; Hudlung-bear - a deity considered to be the master of both mountains and the taiga; the Iron Kirgia - the master of the Manchurian hills; Gurme-hare - a deity living in the hills. These deities are characterized by a peculiar appearance: “....an animal with golden hair grazes there. He has forty bells on his muzzle, there are fifty bells on the back of his neck, and a copper bell - on his jaw and an iron bell - on his chin. His name is Gurmehare" [12].

Nanaian totem deity nominations are fewer than those in Australian folktales: fox, hare, elk, bear, wolf, dog, flying squirrel, frog, rat, heron, duck, goose, sturgeon, pike, catfish. A significant difference consists in the pronounced tradition of worshiping waterfowl in the Far East. Both archeological and folklore materials foreground waterfowl - swans, ducks, geese 
as one of the most common subjects for depiction. Eagle acts as one of the main patrons of the shaman, and the main "vehicle" when "flying" to the sky.

The results of the structural analysis are represented in Fig.2.

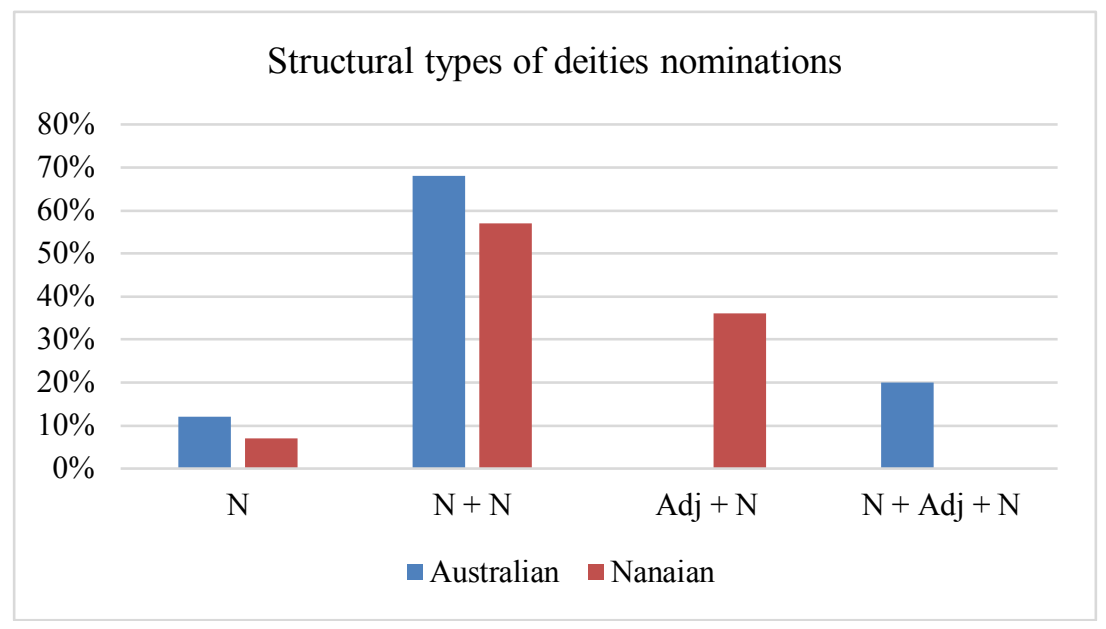

Fig. 2. Structural types of spellonyms- nominations of deities.

As the structural analysis shows, Australian spellonyms are represented by the transcription of the name in the Aboriginal language and its translation. Most names correspond to the structure $\mathbf{N}+\mathbf{N}$, which in some cases can be extended to the structure $\mathbf{N}+$ Adj + N: Oooboon the blue tongued lizard; Beereeun the small, prickly lizard; Bilber the soft-furred sandhill rat; Bubburr the giant brown and yellow snake. Some nominations are formed by reduplication: "Beereeun the lizard wanted to marry Bullai Bullai the green parrot sisters..." [6]. One nomination was formed by means of onomatopoeia: Wah the crow sounds similar to the hunting cry Wah.

Nanaian spellonyms are mostly transcriptions of original names which are either oneword nominations (Padia, Kalgama) or word combinations following the pattern Adj + N: Mue Edeni, Arha Aodinu, Halaton Mohan, Hud Gumun. Only one nomination contains the translated word "god": Yohan-god. In case of totemic deity nominations, the prevalent structural type comprises the proper name and the word denoting the totem animal: Gurmehare, Nangi-bear, Hudlung-bear.

\subsection{Names of celestial bodies}

The names of celestial bodies in Australian folktales include: Yhi the sun; Meamei / the Pleiades; Gwaibillah / the Red Star / Mars; Ghindamaylannah / the Laughing Star / Venus, Bahloo the moon; Brahlgah the Clouds of Magellan. Celestial bodies are totem deities that have changed their appearance. Some of them can assume anthropomorphic forms, for example, Yhi the sun appears in the form of a woman: "Yhi rules in the land until the storms are over and have cooled her" [5].

Bahloo the moon takes the form of a man who descends to the earth, talks to people and returns to the heaven. In the fairy tale "Bahloo the Moon and the Daens", he asks people to carry his dogs across the stream but they refuse to do so because they see snakes instead of dogs. The angry deity carries the dogs across the stream on his own and, as punishment, sends many snakes to the earth.

Other celestial bodies originally had a zoomorphic shape. The Pleiades Meamei / the 
Pleiades are seven sisters from the Bandicoot tribe who witnessed the initiation ceremony of young men and for this reason turned into stars: “... if you look, you may see the seven sisters together. You perhaps know them as the Pleiades, but the black fellows call them the Meamei" [5].

Planet Mars - Gwaibillah / the Red Star arose when two wives from the tribe of lizards were killed by their husbands. The red color symbolizes the inflicted wounds: “... they are now known as Gwaibillah, the red star, so called from its bright red color, owing... to the red marks left by the stakes on the bodies" [5].

Brählgah the Clouds of Magellan are satellite galaxies of the Milky Way that emerged when Brählgah, the native companion birds (large cranes), ascended to the sky.

Nanaian folktale texts contain fewer names of celestial bodies in comparison with Australian folktale texts.

Siun - the sun is a sacred spiritual being that can appear in the guises of both the mothersun and the girl-sun. In fairy tales, the powerful forces of the master spirits of the universe can stop Siun, make it move backwards: from the west to the east, or place it where it should not be at that time. Characters from fairy tales are also marked with solar symbolism. The younger brother Garbildan (literally: galpo - light) is a mergen emitting light, the elder Garildan (literally: gal - fire) is brightly glowing. The image of Garildan is associated with the sunrise, Garbildan - with the sunset. Together with their doublet characters, they follow the path of the Sun: "After that, Garildan and Garbildan began to live and live, not knowing any sorrow. And a person who is going downhill, having reached them, remains with them: there is no further way for him; a person traveling upward, having reached them, remains there: this is where his path ends" [15].

The results of the structural analysis are represented in Fig.3.

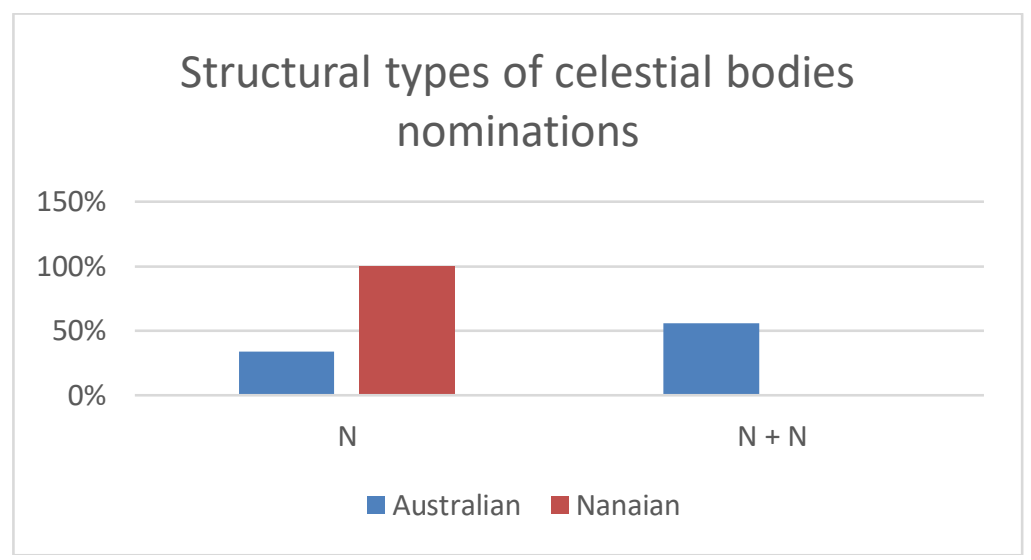

Fig. 3 Structural types of spellonyms - nominations of celestial bodies

\subsection{Names of artefacts}

Australian spellonyms referring to sacred objects and rites include: Minggah, Oodoolay, boomerang, bubberah, Gubberah, Song of the Setting Emu, corrobboree.

Spellonyms are used in the description of wizards' rituals: Minggah - a sacred tree in which the wizard can hide cult objects; Gubberah - magical transparent crystals of the wizard; Oodoolay - a rain-making stone that encloses ancestors' souls.

The Song of the Setting Emu is performed during the nesting period, when the tribe first manages to find a bird incubating chicks. Importance of singing art in the life of the indigenous people cannot be overestimated. During the Dreamtime, when there appeared the earth and life forms on it, the creator gods moved along the "Song Trail" that covered the 
continent in the form of a ramified system. Songs performed in a certain sequence served as a pass for the resident travelling through the territories of various tribes [18]. The importance of songs as a ritual art is confirmed in the fairy tale which narrates about the representatives of the tribe of parrots that sing for their cousin - thunder, trying to make rain: "We will sing to our cousin Dooloomai the Thunder; he will hear us and break a rain cloud for us" [6].

The spellonyms boomerang and bubberah (literally: a returning boomerang) are found in the tale about boys from the tribe of owls who caused a whirlwind with their throws. According to the Dictionary of Australasian Words, the word boomerang originates from the word boomori "wind", which confirms the ability of a sacred object to cause natural phenomena [19].

The spellonym corrobboree / korroboree / karabari / caribberie denotes a sacred festive dance, originating from korobra "to dance". Boroya / beria is also used in the meaning "to sing" [19].

Nanaian spellonyms denoting objects of worship and rites include: buchuen, alkunde, itoan, mugde, panio, toroan, tuige, edeje, senkure, undiuri, chonko. The nominations describing shamans' rituals prevail over nominations of artefacts used in everyday activities.

Ideas about the relationship between people and trees are found in the traditional culture of many Tungus-Manchurian ethnic groups in the Far East. Heroes of folktales often turn to trees for advice and protection. Tuige is a sacred family tree, a Nanaian version of the World Tree. A tall elm, ash or oak located not far from the house, as a rule, at the edge of the forest was chosen and the figurines of spirits-healers and spirits-amulets were placed near it: "Behind the house there were a large toroan and a tuige. So, somebody lives in this place! And if a shaman lives there, it is a mighty shaman!" [12].

The root "tora" (literally: a sacred tree) is found in the nomination toroan - a pillar with a human face engraved on it: "Harirei, harirei, harirei, genaei, behind my house there is an iron toroan, harirei, genaei" [15, 11].During the funeral, a mugde (literally: the root of a tree) - a wooden figure depicting the body and soul of the deceased - was installed near a toroan pillar. Thus, the deceased returned to their roots.

Not only trees, but also plants possess magical powers. Senkure - wild rosemary -is an attribute of cleansing, preserving magic. In fairy tales, senkure is a wonderful remedy. It was believed that if you mix it with saliva and cover the wounds with this mixture, they quickly heal.

Chonko is a hole under the roof of a Nanaian dwelling, oriented to the east. People could communicate with good and evil spirits through the chonko: "Once a huge bird flew to him. It sat down on the lintel - the house reeled. It stuck its beak into the chonko and moved it back and forth - the walls collapsed" [12].

The structural analysis demonstrates that the overwhelming majority of nominations both in Australian and Nanaian folktales are represented by nouns - transcriptions of original nominations. There was only one example of a word combination which is a translation from the Aboriginal language into English: Song of the Setting Emu.

\subsection{Names of magical natural phenomena}

The names of natural phenomena found in the texts of Australian folktales are used mainly in folk poetry: $U$ e hu, Wurrawilberoo, Mayrah the wind, Gheeger Gheeger the cold west wind, Yarrageh the spring wind, Gunyahmoo the south-east wind, Mundehwuddah the northwest wind, Dooloomai the Thunder.

$U$ e $h u$ is a nomination for rain which is used only in folktales and songs.

Wurrawilberoo is a whirlwind with the devil in the center.

In the fairy tale "Beereeun the Mirage Maker" the spellonym Dooloomai the Thunder is represented by the structure $\mathbf{N}+\mathbf{N}$. The kinship of a natural phenomenon and totem deities 
is also mentioned in the text. It is probably for this reason that the spellonym receives the structure characteristic of the nomination of totem deities.

Mayrah the wind is the spring wind driving away the winter and associated with awakening. In the tale "Mayrah, the Wind that Blows the Winter Away" two circumlocutory epithets are used for the spring wind: the lover of all and the bringer of plenty. The synonymous nomination includes the attribute "spring": Yarrageh the spring wind.

The spellonym Gheeger Gheeger the cold west wind is a polynomial structure that includes a doubled stem of native origin and an English attributive phrase. The anthropomorphic qualities are also found here, since the nomination is correlated with the personal pronoun she in the text of the tale.

The spellonyms Gheeger Gheeger the cold west wind, Yarrageh the spring wind, Gunyahmoo the south-east wind, Mundehwuddah the north-west wind are used to denote natural phenomena that gather for festivities and dance like people: "Twice a year the winds all meet, holding great corroborees and wild revellings" [5].

Our sample of Nanaian spellonyms does not include many names of magical natural phenomena. The title of the tale "About the master of the north wind" is actually a spellonym "Ochi edeni", where edeni is a common name for a god.

Tevekse is a cloud which performs an important symbolic function. A white tevekse is a symbol of the good, while a black tevekse is a symbol of the evil. It is the way to the heaven, a means of transportation and communication of heavenly spirits and masters with people.

Agdi (literally: thunderstorm) and agdi grimani (literally: thunderstorm with lightning) represent the heavenly battle of the good forces with demons.

The structural analysis shows that the structure $\mathbf{N}+\mathbf{N}$ is represented both in Australian and Nanaian folktales. The difference concerns the origin of the nouns: in Australian nominations, the second noun is an English translation of a natural phenomenon; in Nanaian nominations, both nouns are transcriptions of original names (Fig. 4).

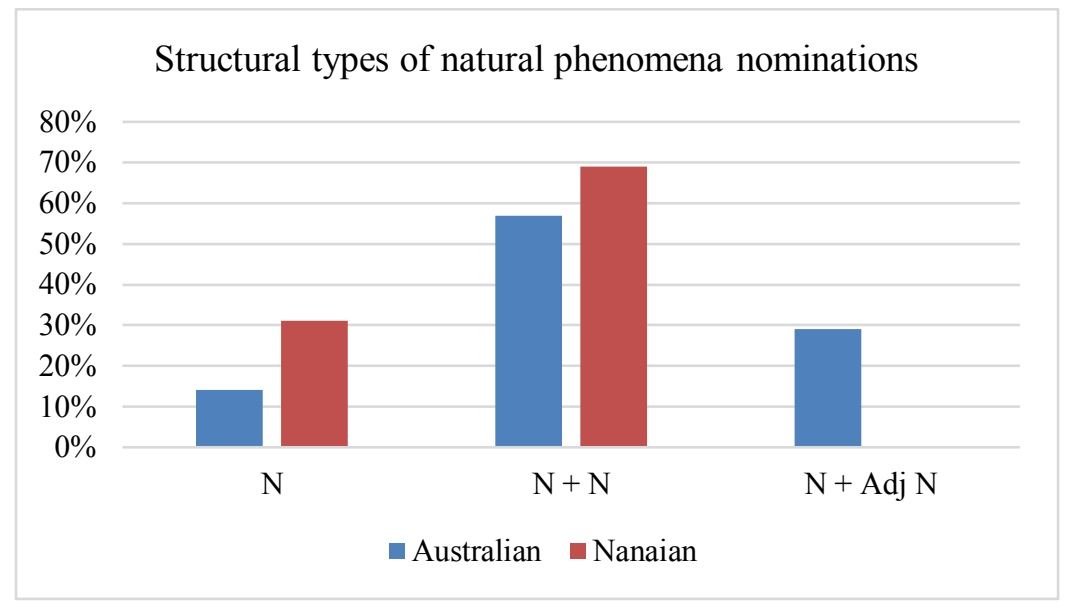

Fig. 4 Structural types of spellonyms - nominations of natural phenomena.

\subsection{Names of magical creatures}

Nominations of Australian magical creatures can be divided into nominations of inhabitants of specific locations and nominations of spirits that do not have a specific habitat. Representatives of the first group are integrated into the environment: Bunyip-a monster that lives in water bodies; Mulloka - devil living in streams; Yawkyawk-mermaid; Mimi-spirits that dwell in the rocks. There are four nominations for spirits which not associated with a 
specific territory: Yara-Ma-Yha-Who - a vampire-like creature; Mullee Mullee - a spirit of dreams, providing patronage; Wallahgooroonbooan - a spirit-messenger of the creator god Byamee; Wondah / Wundah - an evil spirit.

In one of the contexts, the spellonym Wondah is replaced by the epithet the white devil, thus forming a contextual opposition with a representative of the indigenous population - the black fellow, which, presumably, conveys tensions between indigenous people and European settlers.

By analogy with Australian folktales, magical creatures in Nanaian folktales can be divided into nominations of magical beings inhabiting a definite location and nominations of magical beings without a specific habitat. The water element is inhabited by poka / foka-a fantastic creature engaged in malicious deeds: it steals fish from gullible fishermen; simur / simun - a mythical serpent which lives in lakes and feeds on lotus; temusevensel - a common name for all kinds of water spirits that inhabit the sea, rivers, lakes, swamps and streams; chakhan mafa - a fantastic monster with a serpentine body and a bird's head that brings evil to people by stealing beautiful girls and harassing mergens; puimur - a fantastic creature in the guise of a catfish: "...the water above the river rose as a fountain as high as the chimney of a house and a puimur appeared on the surface" [12].

The land element is represented by harpoon - a taiga spirit in the guise of a leopard; Sakharin Dyabdyan - a Black Dragon, representative of the dark, evil forces of nature; hosaktaku-mama - a bloodthirsty monster in the form of a clawed old woman; kai - an evil spirit in the guise of a bear.

Seven is a shaman's helper spirit. Sevens are presented in a zoomorphic form (beast, bird, fish, reptile), but have anthropomorphic faces and can understand the shaman's speech, answer him and carry out his instructions: "We are not people. We are your parents' most important Sevens. We have been with earthly people for a long time" [12].

There was a reference to an ogre with a proper name in our sample: "There lived Spit with his sister. He was an ogre and hunted people" [12].

A special place in folktales is given to pudins / fudins - spirits that turn into beautiful girls: "Behind this hill is the river. In the middle of it is a glass coffin. There is a pudin in that coffin, which is the most beautiful in the world" [12]. Interestingly, pudins are magical creatures that are always given proper names: pudin Tomdi, pudin Dyargoi, pudin Kekui, pudin Dugbanki.

Having analysed the structure of spellonyms - nominations of magical creatures, we have drawn the conclusion about the prevalence of monolexemic names in both folklore traditions (Fig. 5).

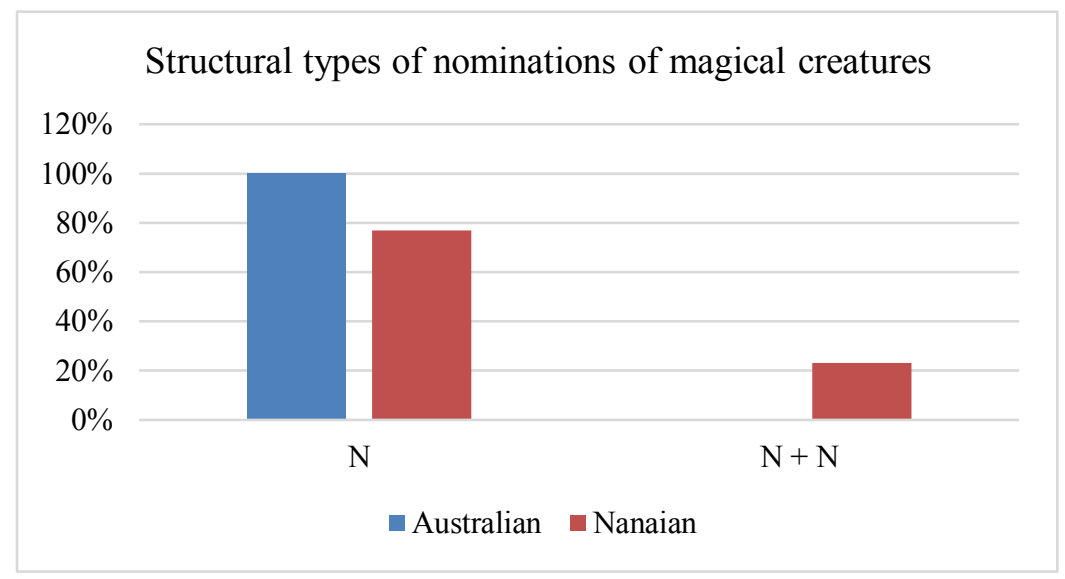

Fig. 5. Structural types of spellonyms - nominations of magical creatures. 


\section{Discussion}

The conducted research allowed us to draw conclusions regarding the folklore worldview of the indigenous population of Australia and the Far East of Russia and the magical nominations that fill it.

1. The degree of integration of the real and the magical is extremely high: the spatial and temporal characteristics of the magical world, its social structure in many respects repeat the spatial and temporal characteristics and social structure of the real world, and most creatures of magical nature are more likely to be considered progenitors than inhabitants of another world, which is explained by the totemistic ideas of the indigenous population.

2. The nature of magical creatures is dual, they are able to change their physical shape: anthropomorphic and zoomorphic properties are combined in totem deities, whose number prevails in Australian aetiological tales, and magical artefacts, whose number prevails in Nanaian aetiological tales; celestial bodies combine anthropomorphic, zoomorphic and astromorphic properties. We assume that such fluidity of physical shape reflects the uncertainty of the boundaries of the folktale world.

3. In Australian folktales nominations of magical creatures are mostly of native origin, however, the names of totem deities, celestial bodies and natural phenomena are supplemented by an English analogue, forming the structure $\mathbf{N}+\mathbf{N}$ or its less common variant $\mathbf{N}+\mathbf{A d j}+\mathbf{N}$. The use of the definite article in a generalizing function before the second component of the nomination indicates a representative of a whole class of objects, the progenitor, which is consistent with the role of the deity. In some cases, spellonyms are replaced by circumlocutory epithets with a pronounced positive connotation.

The majority of nominations in Nanaian folktales are represented by nouns of native origin transcribed into Russian. In case of the structure Adj $+\mathbf{N}$, the adjective expresses qualities with both positive and negative connotations, e.g. mighty, impetuous, ever-present, bone-dry.

Supposedly, the prevalence of Australian and Nanaian nominations transcribed into English and Russian manifest the collectors' attempts to preserve the local colour of folktales while the translated components of spellonyms make the folktales more understandable for the readers.

4. A magical creature's male or female gender is not fixed in the nomination, however, in the text of the tale there are linguistic means (nouns and personal pronouns) indicating that they are male or female. Based on this, we can assert that the number of "male" and "female" nominations is comparable.

\section{Conclusion}

The culture of any ethnic group is characterized by the desire to explain the world order, to determine the forces that rule over nature and man. The study confirms that the indigenous people of Australia and the Far East of Russia are less characterized by a dualistic worldview, which opposes the material, visible world to the intangible world. "This" and "other" worlds are integrated, which can be clearly seen in folktale texts saturated with culturally significant information. Decoding spellonyms as lexical means conveying national and cultural meanings allows us to determine their role in the creation of artistic images and to confirm that the folklore worldview as part of the national worldview exists in the minds of people in specific, independent forms. 


\section{References}

1. Yu.E. Berezkin, From the Old World to the New World: myths of the peoples around the world (Moscow, AST, Astrel, 2009)

2. E.M. Meletinskiy, The folklore of Australians. Australian Legendary Tales (Moscow, Nauka Publ., 1965)

3. B. Scott, Lies, Flies and Strange Big Fish: Tall Tales from the Bush. (St. Leonards, New South Wales, Allen \& Unwin, 2000)

4. D. Haase, The Greenwood encyclopedia of folktales and fairytales (Westport, Conn., Greenwood Press, 2008)

5. K. Langloh Parker, Australian Legendary Tales (Charleston, Nabu Press, 2011)

6. K. Langloh Parker, More Australian Legendary Tales (Charleston, Nabu Press, 2011)

7. W. Ramsey Smith, Myths and Legends of the Australian aboriginals (New York, Farrar and Rinehart Publishers, 1932)

8. G. Seal, The Hidden Culture: Folklore in Australian Society (Melbourne, Oxford University Press, 1989)

9. B. Davey, G. Seal, The Oxford Companion to Australian Folklore (Melbourne, New York, Oxford University Press, 1993)

10. R.M. Berndt, C.H. Berndt, The Speaking Land: Myth and Story in Aboriginal Australia (Ringwood, Victoria, Penguin Books, 1989)

11. M.A. Orbell, Concise Encyclopedia of Maori Myth and Legend (Christchurch, Canterbury University Press, 1998)

12. N.B. Kile, The Nanai folklore: Ningman, Siokhor, Telungu (Novosibirsk, Nauka. Siberian publishing house RAS, 1996)

13. History and culture of the Nanai: historical and ethnographic essays (St. Petersburg, Nauka, 2003)

14. M.A. Kaplan, The main genres of the Nanai folklore: Ningman-fairy tales and Telungu - legends (Moscow, Nauka Publ., 1949)

15. Yu.A. Sem, Nanai. Material culture (second half of the 19th century - mid-20th century). Ethnographic essays (Vladivostok, Nauka, 1973)

16. O.V. Belova, G.I. Kabakova The origins of the world: Russian aetiological tales and legends (Moscow, FORUM; NEOLITH, 2014)

17. M. Morford, R.G. Lenardon, Classical Mythology (New York, Oxford, OUP, 2007)

18. V. V. Oshchepkova, N. V. Solovyeva, Bulletin of Moscow Region State University Series: Linguistics 2, 73-87 (2018)

19. E. Morris, Austral English: A Dictionary of Australasian Words (Sydney, Forgotten Books, 2012) 